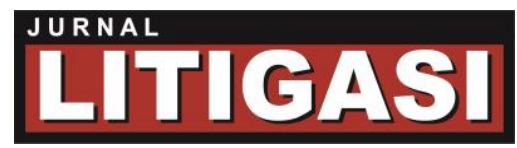

Available online at: http://ejournal.unpas.ac.id/index.php/litigasi

Litigasi, Vol. 20 (2) Oktober, 2019, p.267-290

DOI: http://dx.doi.org/10.23969/litigasi.v20i2.1561

\title{
DUALISME PENERAPAN HUKUM BAGI PELAKU KEKERASAN SEKSUAL TERHADAP ANAK
}

\author{
AMRINA HABIBI ACHMAD \\ Magister IImu Hukum Fakultas Hukum Universitas Syiah Kuala (UNSYIAH), Jl. Putroe Phang No. 1 \\ Darussalam Aceh, Email: amrinahabibi@yahoo.com
}

\begin{abstract}
ABSTRAK
Hukum nasional yang menggatur perlindungan anak telah mengatur bahwa setiap anak berhak untuk memperoleh perlindungan salah satunya dari kejahatan seksual dan memberikan kewenangan mengadili kasus tersebut kepada Pengadilan Anak yang berada di bawah pengadilan negeri. Tetapi di sisi lain Hukum lokal yang berlaku di Aceh mengatur bahwa kewenangan mengadili kasus kekerasan seksual terhadap anak kepada Mahkamah Syar'iyah. Kedua peraturan tersebut menimbulkan dualisme hukum yang mengatur kasus yang sama di wilayah hukum Aceh, sehingga dapat menimbulkan masalah dalam penegakannya. Artikel ini bermaksud menyoal implementasi kewenangan absolut lembaga peradilan dalam penyelesaian perkara kekerasan seksual terhadap anak di Aceh, serta menjelaskan penerapan sanksi bagi pelaku kekerasan seksual terhadap anak. Artikel ini merupakan hasil penelitian yang menggunakan metode yuridis emiris. Implementasi Kewenangan absolut pada lembaga peradilan terkait penyelesaian perkara kekerasan seksual terhadap anak di wilayah hukum Aceh, pengadilan negeri yang kewenangannya diberikan oleh hukum nasional lebih berwenang dibandingkan dengan Mahkamah Syar'iyah yang kewenangannya diberikan oleh hukum lokal. Salah satu alasan diantara beberapa alasan adalah karena Hakim pengadilan negeri pada umumnya telah memiliki sertifikat khusus anak, sedangkan hakim Mahkamah Syar'iyah saat penelitian dilakukan belum memiliki hakim bersertifikat khusus anak.
\end{abstract}

Kata Kunci: Dualisme, Hukum, Kekerasan Seksual, Anak. 
Available online at: http://ejournal.unpas.ac.id/index.php/litigasi

Litigasi, Vol. 20 (2) Oktober, 2019, p.267-290

DOI: http://dx.doi.org/10.23969/litigasi.v20i2.1561

\begin{abstract}
National law regulating child protection stipulates that every child has the right to secure protection, one of which is from sexual crimes, and gives the authority to adjudicate the case to the juvenile court under the district court. But on the other hand, the local law in force in Aceh stipulates that the authority is to adjudicate cases of sexual violence against children to the Sharia Court. Both of these regulations give rise to legal dualism that governs the same case in the Aceh jurisdiction, so that it can cause problems in its enforcement. This article intends to question the implementation of the absolute authority of the judiciary in the resolution of cases of sexual violence against children in Aceh, and explains the application of sanctions for perpetrators of sexual violence against children. This article is the result of a research that uses the juridical empiric method. Implementation of absolute authority in judicial institutions related to the settlement of cases of sexual violence against children in the jurisdiction of Aceh, district courts whose authority is given by national law are more competent than the Sharia Court whose authority is given by local law. One of the reasons among many is because district court judges generally have special certificates for adjudicating cases involving children, while the judge of the Sharia Court did not.
\end{abstract}

Keywords: Dualism, Law, Sexual Abuse, Child.

Copyright @ 2019, LITIGASI, p-ISSN: 0853-7100; e-ISSN: 2442-2274 


\section{PENDAHULUAN}

Pasal 10 Undang-Undang Nomor 48 Tahun 2009 tentang Kekuasaan Kehakiman (UU Kekuasaan Kehakiman) menyebutkan bahwa kekuasaan kehakiman dilakukan oleh sebuah Mahkamah Agung dan badan peradilan yang berada di bawahnya dalam lingkungan peradilan umum, lingkungan peradilan agama, lingkungan peradilan militer, lingkungan peradilan tata usaha negara dan oleh sebuah Mahkamah Konstitusi. R. Soeroso membagi kewenangan mengadili menjadi dua kekuasaan kehakiman, yakni kekuasaan kehakiman atribusi dan kekuasaan kehakiman distribusi. Atribusi kekuasaan kehakiman adalah kewenangan mutlak, atau juga disebut kompetensi absolut. Yakni kewenangan badan pengadilan di dalam memeriksa jenis perkara tertentu dan secara mutlak tidak dapat diperiksa oleh badan pengadilan lain. Sedangkan tentang distribusi kekuasaan pengadilan atau apa yang dinamakan kompetensi relatif, atau kewenangan nisbi, yakni bahwa pengadilan negeri ditempat tergugat tinggal (berdomisili) yang berwenang memeriksa gugatan atau tuntutan hak (Soeroso, 2001).

Menurut Roihan Rasyid, kewenangan seringkali juga dimaknai kompetensi dan juga dimaknai dengan kekuasaan. Adapun kewenangan yang dimaksud disini adalah kewenangan mengadili oleh lembaga peradilan. Roihan Rasyid membagi kewenangan menjadi dua yaitu kewenangan relatif dan kewenangan absolut. Kewenangan relatif diartikan sebagai kekuasaan pengadilan yang satu jenis dan satu tingkatan, dalam perbedaannya dengan kekuasaan pengadilan yang sama jenis dan sama tingkatan lainnya atau dengan kata lain bahwa setiap lembaga peradilan mempunyai wilayah hukum tertentu, dalam hal ini meliputi satu kotamadya atau satu kabupaten. Kewenangan absolut artinya kekuasaan pengadilan yang berhubungan dengan jenis perkara atau jenis pengadilan, atau tingkatan pengadilan, dalam perbedaanya dengan jenis perkara atau jenis pengadilan, atau tingkatan pengadilannya. Misalnya, pengadilan agama

Copyright $\odot$ 2019, LITIGASI, p-ISSN: 0853-7100; e-ISSN: 2442-2274 
berkompeten atas perkara perkawinan bagi mereka yang beragama Islam, sedangkan bagi yang selain Islam menjadi kompetensi peradilan umum (Rasyid, 2007).

Lahirnya Undang-Undang Nomor 23 Tahun 2002 yang telah diubah dengan Undang-Undang Nomor 35 Tahun 2014 tentang Perlindungan Anak (UUPA) merupakan suatu rangkaian upaya yang dilakukan negara demi mewujudkan terpenuhinya kesejahteraan anak. Negara dalam hal ini diwakili oleh lembaga-lembaga atau satuan perangkat kerja pemerintah pada berbagai level baik nasional, provinsi maupun kebupaten atau kota berkewajiban untuk kemudian memastikan implementasi di tingkat teknis sesuai dengan batas kewenangan masing-masing. Perlindungan anak dalam UUPA memberikan definisi apa yang dimaksud dengan perlindungan anak yaitu: "segala kegiatan untuk menjamin dan melindungi anak dan hak-haknya agar dapat hidup, tumbuh, berkembang dan berpartisipasi secara optimal sesuai dengan harkat dan martabat kemanusiaan, serta mendapatkan perlindungan dari kekerasan dan diskriminasi".

Pasal 15 UUPA menyatakan secara tegas bahwa "Setiap anak berhak untuk memperoleh perlindungan dari berbagai tindak kejahatan termasuk kejahatan seksual". Sebagaimana yang disebut di atas, salah satu upaya perlindungan terhadap anak yang diatur dalam UUPA adalah perlindungan terhadap kekerasan dan kejahatan seksual, baik terhadap anak perempuan maupun laki-laki. Menurut Achie Sudiarti Luhulima, pengertian kekerasan seksual adalah kejahatan yang berkaitan dengan perkelaminan atau seksualitas dan lebih khusus bagi yang berkaitan dengan seksualitas laki-laki dan perempuan (Luhulima, 2000). Sedangkan menurut Susilawati, kekerasan seksual pada umumnya diartikan sebagai perbuatan pidana yang berkaitan dengan seksualitas atau perkawinan yang dapat dilakukan oleh laki-laki atau perempuan (Susilawati, 2001). Definisi tentang kekerasan seksual atau yang berhubungan dengan seksualitas yang tidak diinginkan oleh salah satu pihak yang menyebabkan salah

Copyright $\odot$ 2019, LITIGASI, p-ISSN: 0853-7100; e-ISSN: 2442-2274 
satu pihak tersebut tidak rela atau tidak memiliki kerelaan yang menyebabkan terjadinya pemerkosaan.

Kekerasan seksual yang pada umumnya dapat terjadi kepada laki-laki maupun terhadap perempuan dewasa, namun kini telah mengintai anak-anak, khususnya di Aceh. Menimbang bahwa anak bukan hanya memerlukan perlindungan dari orang tua, melainkan juga dari masyarakat dan pemerintah. Oleh karena itu, dibentuklah sebuah aturan perlindungan anak melalui hukum lokal Aceh yaitu dalam Qanun Aceh Nomor 11 tahun 2008 tentang Perlindungan Anak (Qanun Perlindungan Anak). Qanun Perlindungan Anak dalam Pasal 1 angka 17 mendefinisikan kekerasan yakni semua bentuk kekerasan fisik, mental dan seksual yang berakibat timbulnya cacat atau luka yang mengenai tubuh atau pikiran. Kekerasan seksual anak adalah perbuatan atau tindakan seksualitas yang dilakukan terhadap anak baik perempuan maupun laki-laki yang masih berumur dibawah 18 tahun.

Di Indonesia, pengadilan yang berwenang menyelesaikan kasus kekerasan seksual pada anak adalah Pengadilan Khusus Anak yang berada di bawah pengadilan umum. Akan tetapi, semenjak diberlakukannya Qanun Jinayat, selain ada pada Pengadilan Anak, kewenangan mengadili kasus kekerasan seksual pada anak juga diberikan kepada Mahkamah Syar'iyah yang berada di bawah pengadilan agama, khususnya di Aceh. Kewenangan tersebut didasarkan pada Pasal 47 Qanun Aceh Nomor 6 Tahun 2014 tentang Hukum Jinayat (Qanun Jinayat) yang berbunyi: "Setiap orang yang dengan sengaja melakukan jarimah pelecehan seksual sebagaimana yang dimaksud dalam Pasal 46 terhadap anak, diancam dengan uqubat ta'zir cambuk paling banyak 90 (sembilan puluh) kali atau denda paling banyak 900 (sembilan ratus) gram emas murni atau penjara paling lama 90 (sembilan puluh) bulan".

Adanya dualisme aturan hukum mengenai penyelesaian kasus kekerasan seksual pada anak, yaitu UU Peradilan Anak dan Qanun Jinayat menimbulkan

Copyright $@$ 2019, LITIGASI, p-ISSN: 0853-7100; e-ISSN: 2442-2274 
tumpang tindih kewenangan 2 (dua) lembaga peradilan khusus, yaitu Pengadilan Anak yang berada di bawah peradilan umum, dan Mahkamah Syar'iyah yang berada di bawah peradilan agama. Tumpang tindih kewenangan pada lembaga peradilan tersebut dalam menyelesaikan suatu perkara yang sama oleh 2 (dua) lembaga peradilan yang berbeda sehinga dapat menimbulkan persoalan bagi korban dalam upaya mencari kepastian hukum. Berdasarkan uraian di atas, artikel ini berusaha menyoal implementasi kewenangan absolut pada lembaga peradilan terkait penyelesaian perkara kekerasan seksual terhadap anak di Aceh.

\section{PEMBAHASAN}

Berlakunya dualisme Hukum Pidana yang mengatur tentang kewenangan 2 (dua) lembaga peradilan yang mengadili kasus kekerasan seksual terhadap anak di Aceh menimbulkan permasalahan dalam pelaksanaannya, serta memberikan kesan ketidakadilan dan kebingungan bagi para pencari keadilan sekaligus pandangan yang beragam tentang kewibawaan lembaga penegak hukum. Pasal 1 angka 2 Undang-Undang Nomor 35 Tahun 2014 tentang Perubahan Atas Undang-Undang Nomor 23 Tahun 2002 tentang Perlindungan Anak (selanjutnya disebut UUPA) menyatakan bahwa "Perlindungan anak adalah segala kegiatan untuk menjamin dan melindungi anak dan hak-haknya agar dapat hidup, tumbuh, berkembang dan berpartisipasi secara optimal sesuai dengan harkat dan martabat kemanusiaan, serta mendapatkan perlindungan dari kekerasan dan diskriminasi". Selanjutnya dalam Pasal 15 UUPA juga menyatakan secara tegas bahwa "Setiap anak berhak untuk memperoleh perlindungan dari penyalahgunaan dalam kegiatan politik, pelibatan dalam sengketa bersenjata, pelibatan dalam kerusuhan sosial, pelibatan dalam peristiwa yang mengandung unsur Kekerasan, pelibatan dalam peperangan dan kejahatan seksual".

Sebagaimana yang telah disebutkan di atas, salah satu upaya perlindungan terhadap anak yang diatur dalam UUPA adalah perlindungan terhadap kekerasan

Copyright $\odot$ 2019, LITIGASI, p-ISSN: 0853-7100; e-ISSN: 2442-2274 
dan kejahatan seksual, baik terhadap anak perempuan maupun laki-laki. Sebagaimana yang telah diketahui, bahwa UUPA memberikan kewenangan mengadili kasus kekerasan seksual terhadap anak kepada Pengadilan Anak yang merupakan pengadilan khusus yang berada di bawah pengadilan negeri. Sehingga secara tidak langsung menyatakan bahwa kasus kekerasan seksual pada anak merupakan kewenangan absolut/mutlak dari pengadilan negeri di Indonesia, termasuk di Aceh. Akan tetapi Qanun Jinayat mengatur berbeda. Pasal 47 Qanun Aceh Nomor 6 Tahun 2014 tentang Hukum Jinayat (Qanun Jinayat) yang berbunyi: "Setiap orang yang dengan sengaja melakukan jarimah pelecehan seksual sebagaimana yang dimaksud dalam Pasal 46 terhadap anak, diancam dengan uqubat ta'zir cambuk paling banyak 90 (sembilan puluh) kali atau denda paling banyak 900 (sembilan ratus) gram emas murni atau penjara paling lama 90 (sembilan puluh) bulan". Kemudian pada Pasal 50 Qanun Jinayat diatur bahwa: "Setiap orang yang dengan sengaja melakukan jarimah perkosaan sebagaimana dimaksud dalam Pasal 48 terhadap anak diancam dengan uqubat takzir cambuk paling sedikit 150 kali, paling banyak 200 kali atau denda paling sedkit 1500 gram emas murni paling banyak 2000 gram emas murni atau penjara paling singkat 150 bulan, paling lama 200 bulan".

Berdasarkan pasal-pasal di atas, diketahui bahwa terdapat aturan hukum lainnya yang mengatur tentang kekerasan seksual terhadap anak, yaitu Qanun Jinayat yang memberikan kewenangan mengadili kepada Mahkamah Syar'iyah. Mahkamah Syar'iyah merupakan pengadilan khusus di Aceh yang dikenal ditempat lain dengan sebutan pengadilan agama. Qanun jinayat sebagai salah satu ketentuan hukum yang berlakunya dalam konteks lokal keiistimewaan Aceh ternyata dalam salah satu pasalnya mengunci dan memberi batasan pengaturan untuk menundukkan diri terhadap satu perbuatan melanggar hukum sebagaimana disebut dalam Pasal 72. Disebutkan juga bahwa dalam hal ada perbuatan jarimah sebagaimana diatur dalam Qanun dan diatur juga dalam Kitab Undang-Undang

Copyright ( 2019 , LITIGASI, p-ISSN: 0853-7100; e-ISSN: 2442-2274 
Hukum Pidana (KUHP) atau ketentuan pidana di luar KUHP, yang berlaku adalah aturan Jarimah dalam Qanun ini.

Kedua aturan hukum di atas menimbulkan dualisme hukum yang mengatur satu tindak pidana yang sama dengan memberikan kewenangan mengadili kepada 2 (dua) lembaga peradilan yang berbeda. Keberadaan 2 (dua) aturan hukum yang mengatur satu kasus yang sama, telah menyebabkan kebingungan dalam kalangan masyarakat dalam rangka mencari keadilan dan penyelesaian kasus yang dialami, terutama kasus kekerasan seksual pada anak. Kasus anak merupakan kasus khusus yang harus ditangani oleh peradilan khusus dengan cara dan perlakuan-perlakuan khusus sebagaimana yang telah diatur dalam Undang-Undang Nomor 11 Tahun 2012 tentang Sistem Peradilan Pidana Anak (UU SPPA). UU SPPA mengamanatkan penyelesaian kasus kekerasan terhadap anak kepada Pengadilan Anak yang berada di bawah pengadilan negeri, terlebih dengan kasus kekerasan seksual terhadap anak baik pemerkosaan maupun pelecehan seksual yang umumnya dilakukan oleh orang yang dikenal anak bahkan terkadang memiliki relasi kuasa yang sangat dekat seperti ayah kandung, ayah tiri, abang kandung atau tetangga dan lainnya tentu akan berdampak sangat dalam dan sekaligus mengganggu stabilitas hubungan dalam masyarakat yang berujung pada reviktimisasi kepada korban, korban yang sudah jadi korban menjadi korban berikutnya ketika proses hukum yang berjalan tidak sesuai dengan harapan.

Hasil wawancara dengan Ayu Ningsih yang merupakan Komisioner Komisi Perlindungan dan Pengawasan Anak Aceh, menyatakan pandangannya terkait aturan hukum dan kewenangan lembaga peradilan dalam penyelesaian kasus kekerasan seksual pada anak. Pendapat diberikan dengan meninjau pada Pasal 47 Qanun Jinayat dan Pasal 81 UUPA. Sebagaimana telah disebutkan di atas Pasal 47 Qanun Jinayat memberikan hukuman kepada pelaku kekerasan seksual pada anak dengan uqubat ta'zir cambuk paling banyak 90 (sembilan puluh) kali, atau denda paling banyak 900 gram emas murni, atau penjara paling lama 90

Copyright $\odot$ 2019, LITIGASI, p-ISSN: 0853-7100; e-ISSN: 2442-2274 
(sembilan puluh) bulan atau sama dengan 7 (tujuh) tahun 6 (enam) bulan. Sedangkan Pasal 81 UUPA memberikan hukuman kepada pelaku yang melanggara Pasal 76 D UUPA dengan pidana penjara paling singkat 5 (lima) tahun dan paling lama 15 (lima belas) tahun dan denda paling banyak Rp. 5.000.000.000,00 (lima miliar rupiah)". Adapun Pasal 76 D mengatur "Setiap orang dilarang melakukan Kekerasan atau ancaman kekerasan memaksa anak melakukan persetubuhan dengannya atau dengan orang lain". Dan ketika tindak pidana itu dilakukan oleh orang yang memiliki hubungan relasi keluarga dan darah maka hukuman yang dijatuhkan bisa ditambah sepertiga dari hukuman pokok.

Berdasarkan perbandingan kedua pasal yang mengatur tentang sanksi terhadap pelaku tindak pidana kekerasan seksual terhadap anak, maka dapat dilihat bahwa aturan hukum yang menjerat pelaku sebagaimana yang terdapat dalam Qanun Jinayat, jauh lebih ringan/rendah dibandingkan dengan sanksi yang diatur di dalam UUPA. Menurut Ayu, pelaku kekerasan seksual terhadap anak merupakan pelaku kejahatan kemanusiaan dan oleh karena itu pelaku harus mendapatkan hukuman semaksimal mungkin. Tujuannya adalah agar pelaku maupun calon-calon pelaku lainnya mendapatkan efek jera. Pemberian hukuman cambuk kepada pelaku kekerasan seksual terhadap anak, di satu sisi akan memberikan dampak traumatis yang begitu luar biasa bagi korban kekerasan seksual. Hal ini dikarenakan setelah pelaku mendapatkan eksekusi hukuman cambuk, langsung setelahnya pelaku akan kembali ke lingkungan dan komunitasnya. Sehingga dapat dipastikan pelaku akan bertemu lagi dengan korban. Sementara korban masih dalam keadaan trauma dan belum siap bertemu dengan pelaku. Dengan kondisi seperti ini, korban akan menjadi sangat rentan menjadi korban untuk kesekian kalinya. Belum lagi ditambah dengan adanya ancaman maupun teror yang didapatkan dari pelaku dan keluarganya serta cemoohan dari masyarakat sekitar.

Copyright ( 2019 , LITIGASI, p-ISSN: 0853-7100; e-ISSN: 2442-2274 
Berdasarkan keterangan yang telah disebutkan di atas, dalam rangka penegakan hukum serta mencapai keadilan bagi korban, maka akan lebih baik jika penyelesaian kasus kekerasan seksual terhadap anak dilakukan dengan menggunakan UUPA dengan memberikan memberikan kewenangan mengadili kepada Pengadilan Anak yang berada di bawah pengadilan negeri. Semestinya, kasus-kasus kekerasan seksual terhadap anak tetap harus diproses di pengadilan negeri. Dikarenakan akan jauh lebih efektif dan memberikan efek jera dengan mengingat hukuman yang diberikan oleh UUPA kepada pelaku akan lebih berat jika dibandingkan dengan hukuman yang diatur dalam Qanun Jinayat. Seharusnya dilakukan revisi terhadap Qanun Jinayat dengan membuat pengecualian pemeriksaan terhadap kasus kekerasan seksual pada anak dengan mengacu kepada UUPA dan diproses di Pengadilan Anak yang berada di bawah pengadilan negeri. Tidak hanya dengan menyebutkan pengecualian untuk kasus-kasus yang pelakunya anak saja yang merujuk kepada UU SPPA.

Di sisi lain kendati pun kasus kekerasan seksual pada anak harus ditangani oleh Mahkamah Syar'iyah, semestinya hakim dapat memberikan hukuman maksimal kepada pelaku sehingga dapat memberikan efek jera dan tidak lagi menetapkan atau memilih hukuman cambuk saja kepada pelaku. Jika memang kedepannya kewenangan akan tetap diberikan kepada Mahkamah Syar'iyah, maka kepada hakim Mahkamah Syar'iyah harus diberikan pembekalan dan peningkatan kapasitas UUPA, agar hakim Mahkamah Syar'iyah memiliki perspektif anak sehingga dalam proses pemeriksaan akan menghindari peluang menjadikan status anak yang pada awalnya sebagai korban berubah menjadi pelaku karena dianggap melakukan hal tersebut atas dasar suka sama suka.

Berdasarkan wawancara dengan Norma Manalu, Presidium Balai Syura bahwa jika dilihat dari sisi kewenangan, baik UUPA maupun Qanun Jinayat sama-sama telah memiliki kewenangan dalam mengadili kasus kekerasan seksual terhadap anak, akan tetapi, apabila dilihat dari segi keadilan, akan lebih baik jika penyelesaiannya menggunakan UUPA. Hal ini dikaitkan dengan pilihan hukum

Copyright $\odot$ 2019, LITIGASI, p-ISSN: 0853-7100; e-ISSN: 2442-2274 
yang dijatuhkan berdasarkan Qanun Jinayat, tidak berbanding lurus dengan efek jera dan masa pemulihan bagi korban sebagaimana yang telah dinyatakan dalam UUPA. Berdasarkan Qanun Jinayat, 1 (satu) hari setelah pelaku dieksekusi dengan hukuman cambuk, pelaku dapat langsung pulang dan berpotensi besar akan mengulangi melakukan perbuatan kekerasan seksual pada anak yang sama atau bahkan pada anak-anak yang lainnya. Hal ini disebabkan karena pelaku tidak mendapatkan efek jera dengan hukuman yang telah dijatuhkan. Namun di sisi lain, bebasnya pelaku dikhawatirkan akan menimbulkan dampak psikologis bagi korban dan keluarganya yang sedang berupaya pulih dari trauma. Kondisi ini juga memberikan peluang untuk terjadinya kasus-kasus lain yang serupa, terutama bagi keluarga korban yang belum bisa menerima keadaan tersebut dan masih dalam keadaan emosional jika melihat pelaku.

Berikut perbandingan penggunaan UUPA dan Qanun jinayat terkait kewenangan Pengadilan Anak dan Mahkamah Syar'iyah dalam menyelesaikan kasus kekerasan seksual pada anak di Aceh.

a. UUPA menetapkan hukuman penjara yang makismal dan tinggi kepada pelaku bahkan dengan pemberatan hukuman bagi pelaku dengan durasi waktu tertentu. Dengan demikian, terdapat masa bagi korban untuk melakukan pemulihan tanpa adanya gangguan dengan kehadiran pelaku di sekitarnya. Sedangkan berdasarkan Qanun Jinayat, setelah pelaku dieksekusi hukuman cambuk, maka satu hari setelahnya pelaku telah bebas dan pulang kembali kekomunitasnya, bahkan dapat bertemu dengan korban dan menggangu psikologis korban sekaligus nilai keadilan bagi korban.

b. UUPA tidak membebani pembuktian kepada korban, di mana di dalam Qanun Jinayat tidak diatur pembuktian.

c. UUPA memberikan persyaratan bagi hakim yang akan mengadili kasus anak harus memiliki sertifikat khusus anak. Sedangkan Mahkamah Syar'iyah yang

Copyright $@$ 2019, LITIGASI, p-ISSN: 0853-7100; e-ISSN: 2442-2274 
berlandaskan Qanun Jinayat, tidak mengatur ketentuan bagi hakim yang mengadili kasus anak untuk memiliki sertifikat khusus anak.

d. Mahkamah Syar'iyah tidak terbiasa dengan kasus pidana, karena kewenangannya adalah hukum keperdataan sehingga dapat mempengaruhi hakim saat memutuskan perkara.

e. Qanun Jinayat bersifat lokal dan pendanaannya harus masuk dalam Anggaran Pendapatan dan Belanja Aceh (APBA) atau Anggaran Pendapatan dan Belanja Kabupaten/Kota (APBK). Di mana kapasitasnya kecil dibanding kebutuhannya yang besar. Termasuk pendanaan bagi peningkatan kapasitas aparat penegak hukum, fasilitas yang layak untuk mendukung korban, hingga saat ini belum satupun terpenuhi. Pendanaan operasional Mahkamah Syar'iyah yang berasal dari Anggaran Pendapatan dan Belanja Negara (APBN) untuk penerapan Qanun Jinayat, akan berpeluang digunakan untuk perkara keperdataan.

Berasarkan hasil wawancara dengan Taufik Riswan, Direktur KAPHA Aceh, menyatakan dengan tegas bahwa dalam rangka penyelesaian kasus kekerasan seksual pada anak akan lebih tepat jika menggunakan UUPA. Hal ini dikarenakan UUPA berisikan pemberatan hukuman bagi pelaku, yaitu hukuman maksimal yang ditetapkan dalam UUPA adalah 15 (lima belas) tahun penjara serta denda maksimal sebesar Rp 300.000.000,- (tiga ratus juta rupiah). Selain itu, UUPA juga memberikan kepastian hukum serta proses hukum yang dapat lebih memberikan keadilan bagi korban. Menurut Rosmawardani Muhammad, Wakil Ketua Mahkamah Syar'iyah Aceh bahwa Qanun Jinayat merupakan pemberian kewenangan pemerintah dan harus dilaksanakan sebagai bentuk komitmen pemerintah daerah secara komprehensif. Ada sekitar 20 jarimah lain yang perlu diatur. Qanun Jinayat perlu disosialisasikan secara meluas terutama kepada aparat penegak hukum dan dengan penguatan Sumber Daya Manusia (SDM) yang mumpuni serta penyediaan sarana prasarana yang cukup. Proses eksekusi ketika hukum cambuk yang dipilih tidak boleh dilakukan di hadapan

Copyright $\odot$ 2019, LITIGASI, p-ISSN: 0853-7100; e-ISSN: 2442-2274 
anak. Cambuk memiliki efek tadabbur ketika dilakukan diruang terbuka, tapi dari sisi psikologi anak yang melihat tidaklah tepat. Pemberlakuan Qanun jinayat juga harus mendapatkan komitmen dan dipahami secara utuh oleh para bupati/walikota sehingga dapat memastikan prasarana, penganggaran dan personalia seluruh instansi yang terlibat dapat secara maksimal melakukan dan memastikan implementasi Qanun Jinayat dan tidak terkesan setengah hati karena akan berdampak negatif dalam pandangan masyarakat.

Terlihat bahwa keluarga korban dan korban sendiri memberikan pertanyaan berulang tentang Qanun Jinayat dikarenakan mereka tidak pernah mendengar informasi tentang substansi dari Qanun Jinayat. Hal ini sesuai dengan pendapat dari kepala unit PPA Polresta Aceh Besar yang menyatakan, "kewenangan sosialisasi Qanun berada pada lembaga lain dan Aparat Penegak Hukum (APH) khususnya polisi bertanggung jawab untuk proses penyelidikan dan penyidikan". Selain itu, kefokusan dinas syariat islam sebagai leading sector utama bertugas memastikan implementasi Qanun secara efektif sehingga wibawa aparat hukum terjaga. 2 (dua) kabupaten di Aceh yang tidak pernah menggunakan Qanun Jinayat dalam penyelesaian kasus kekerasan seksual adalah Banda Aceh dan Bireun. Di lain sisi, tidak serempaknya penyelesaian Qanun juga menuai kontroversi.

Pemerintah pusat dalam hal ini Mahkamah Agung (MA) telah menunjukkan kemajuan dimana penyelesaian perkara jinayat oleh Mahkamah Syar'iyah telah dimuat dalam laporan tahunan MA, dan juga sudah ada panitia muda jinayat sejak tahun 2016 sebagai bentuk pengakuan Mahkamah Agung. Di sisi lain, walaupun dalam Qanun Jinayat diatur restitusi, sampai hari ini hanya terdapat 1 (satu) korban yang meminta restitusi. Manakala restitusi dipenuhi, korban tersebut tidak mampu menjalaninya dengan alasan ekonomi. Dalam hal ini, sebagai bentuk konsekuensi pemberlakuan hukum jinayat, baital mal juga harus membangun sistem dalam pemenuhan restitusi bagi korban. Jika merujuk kepada gerakan anti kekerasan seksual terhadap anak, persoalan ini adalah

Copyright $@$ 2019, LITIGASI, p-ISSN: 0853-7100; e-ISSN: 2442-2274 
persolan yang menuntut semua pihak dari hulu sampai ke hilir untuk tanggap dan memberi respon yang cepat, maksimal dan inklusif melalui penyusunan kebijakan daerah, rencana aksi jangka menengah dan tahunan dalam melaksanakan pencegahan dan pemberantasan kejahatan seksual terhadap anak. Upaya dan tindakan sosialisasi mengenai pencegahan dan pemberantasan kejahatan seksual terhadap anak serta meningkatkan koordinasi dengan seluruh unsur Forum Komunikasi Pimpinan Daerah (FORKOMPINDA) dalam mengefektifkan upaya pencegahan dan pemberantasan kejahatan seksual terhadap anak, serta meningkatkan peran aktif aparatur pemerintah daerah dan komunitas lokal dalam pencegahan dan pemberantasan kejahatan seksual terhadap anak dan menyediakan dana dalam anggaran pendapatan dan belanja daerah, serta menyiapkan sumber daya manusia yang kompeten dalam melaksanakan pencegahan dan pemberantasan kejahatan seksual terhadap anak.

Dari sisi jenis hukuman yang dijatuhkan terhadap kasus kekerasan seksual sebaiknya lebih memilih hukuman penjara daripada cambuk. Namun, pelanggar syariat memerlukan penjara khusus, dan juga sebagai bentuk pengawalan dibutuhkan forum pertemuan tingkat tinggi secara rutin sebagai wadah untuk menerima arahan dan pembinaan bagi hakim Mahkamah Syar'iyah. Pemerintah khususnya dinas syariat Islam juga harus melakukan bimbingan teknologi secara terencana kepada aparat penegak hukum dan pihak terkait. Kemudian di dalam Qanun terdapat satu pasal yaitu Pasal 73 Qanun Jinayat yang mengatur tentang zina anak. Seharusnya pasal tersebut tidak ada, karena anak merupakan korban mengingat usia baligh anak saat ini tidak bisa lagi dipersamakan seperti konsep baligh zaman dahulu karena pengaruh makanan dan lainnya.

Menurut Profesor Hamid Sarong, sebagai akademisi, Qanun Jinayat adalah bukti pengakuan kearifan lokal yang sangat luar biasa. Namun dalam praktiknya penerapan syariah di Aceh, khususnya implementasi Qanun tidak terwujud dengan baik karena belum terbangunnya kerjasama yang baik. Berbagai keluhan

Copyright $\odot$ 2019, LITIGASI, p-ISSN: 0853-7100; e-ISSN: 2442-2274 
yang timbul dari pemberlakuan Qanun Jinayat, tetapi sampai hari ini belum ada surat resmi yang menyatakan ada berbagai persoalan terkait pemberlakuan Qanun Jinayat. Sehingga lembaga yang berkaitan dengan implementasi Qanun Jinayat tidak mengetahui secara persis hal-hal yg terjadi dalam masyarakat. Pemerintah Aceh juga dinilai lemah dalam melakukan pemantauan. Zaman modern seperti ini harusnya terjadi pembagian kewenangan sehingga para pihak tidak lagi bekerja sendiri-sendiri. Teori pemisahan kekuasaan sudah tidak lazim dan tidak cocok. Dibutuhkan 1 (satu) jaringan yang tersistem antar institusi aparat penegak hukum maupun institusi lain yang mendukung sehingga Pemerintah Aceh benar-benar memfungsikan diri sebagai pengayom dan jaringan ini harus membangun sinergitas dan dapat memberikan pelayanan yang responsif kepada masyarakat sebagai bentuk membumikan otonomi khusus. Segala upaya harus dilakukan termasuk kebijakan anggaran yang mendukung. Sebagai wujud implementasi sistem presidensil di Indonsesia, maka Gubernur Aceh dalam hal ini diharapkan benar-benar menjadi motor penggerak dan bertanggung jawab secara penuh untuk bergeraknya lembaga-lembaga yudikatif dalam memberikan keadilan yang substantif kepada masyarakat khususnya korban. Qanun Jinayat dalam praktiknya harus menjadi hukum yang hidup atau organik, dan para hakim harus mampu menerjemahkan keputusannya sesuai prinsip kepentingan terbaik bagi anak.

Meskipun saat ini hakim Mahkamah Syar'iyah belum memiliki sertifikat khusus dalam peradilan anak, akan tetapi karena Mahkamah syar'iyah memiliki kewenangan mengurus persoalan hukum keluarga, sehingga mereka memiliki keahlian kepekaaan hati untuk memutuskan perkara yang korbannnya anak secara lebih adil. Qanun Jinayat menjadi proses pembelajaran bersama menuju kepada hukum yang lebih progresif dan responsif. Diharapkan ke depannya pengadilan agama atau Mahkamah Syar'iyah mendapatkan pelimpahan kewenangan sepenuhya sehingga tidak menimbulkan dualisme dalam wilayah hukum untuk memutuskan perkara anak. Tetapi dorongan ini harus dilakukan secara serius

Copyright $@$ 2019, LITIGASI, p-ISSN: 0853-7100; e-ISSN: 2442-2274 
mengingat perhatian pemerintah yang masih rendah, dan pemangku kepentingan serta masyarakat masih menerjemahkan pelaksanaan hukum Islam dengan menggunakan sistem konvensional. Padahal fungsi dakwah sangat besar. Kemudian yang juga harus digali terus menerus adalah bagaimana para hakim dalam mengambil sebuah keputusan memiliki dedikasi yang komprehensif.

Terbuka peluang juga hukuman alternatif yang dirasa tidak adil dari sudut pandang hukum, sehingga seharusnya dapat dilakukan revisi sekaligus evaluasi terhadap Qanun Jinayat agar kejanggalan yang dirasakan tidak menjadi sumber intoleransi dalam masyarakat. Pemberlakuan hukum Islam tentu akan menunjukkan satu kondisi beragamnya karakter dakwah. Karakter dakwah yang dipahami secara umum hanyalah pada ceramah bukanlah satu-satunya alat, tetapi bagaimana tingkah laku menjadi wujud bilhall-nya dakwah seperti sifat jujur, penuh kasih sayang dan sebagainya. Dan juga semestinya pemberlakuan hukum Islam bisa meniru pemberlakuan hukum Inggris (common law), dimana aparat penegak hukum ketika akan mengambil suatu keputusan, minimal akan beristikharah sehingga keputusan itu menjadi keputusan yang adil. Dualisme hukum menimbulkan hambatan dalam pelaksanaan hukum. Apalagi dualisme hukum yang dimaksud memberikan kewenangan menyelesaikan kasus yang sama kepada 2 (dua) lembaga peradilan yang berbeda. Hal ini mengakibatkan tujuan dari pelaksanaan hukum yaitu untuk melindungi kepentingan manusia, serta untuk menciptakan, memelihara dan mempertahankan kedamaian pergaulan hidup menjadi sulit untuk diwujudkan.

Berdasarkan beberapa pandangan di atas, maka diketahui bahwa penyelesaian kasus kekerasan seksual terhadap anak menggunakan UUPA dengan memberikan kewenangan mengadili kepada Pengadilan Anak yang berada di bawah pengadilan negeri, akan memberikan dampak yang lebih menguntungkan bagi pihak korban. Kasus kekerasan seksual terhadap anak merupakan kompetensi absolut bagi pengadilan negeri, khususnya bagi Pengadilan Anak yang merupakan

Copyright $\odot$ 2019, LITIGASI, p-ISSN: 0853-7100; e-ISSN: 2442-2274 
pengadilan khusus yang mempunyai kewenangan dalam menyelesaikan kasuskasus pidana yang melibatkan anak. Hal ini didukung dengan adanya sertifikasi khusus anak bagi para hakim pengadilan negeri, sehingga dalam menyelesaikan kasus kekerasan seksual terhadap anak dilakukan sesuai prosedur-prosedur yang telah ditetapkan dalam peraturan perundang-undangan. Hal ini berbanding terbalik jika penyelesaian kasus kekerasan seksual terhadap anak diselesaikan oleh Mahkamah Syar'iyah yang berlandaskan Qanun Jinayat yang notabennya kompetensi absolutnya adalah kasus keperdataan. Sehingga akan menimbulkan kebingungan bagi para hakim Mahkamah Syar'iyah dalam memutuskan perkara pidana terlebih perkara pidana khusus seperti kasus kekerasan seksual terhadap anak. Yang mana pada dasarnya kasus yang melibatkan anak merupakan kasus yang memerlukan keahlian khusus dalam penanganan dan penyelesaiannya. Dikarenakan subyek dalam kasus ini adalah anak, dimana dalam menghadapi anak harus dengan prosedur-prosedur tertentu sehingga tidak menyebabkan penekanan mental terhadap anak yang dapat berakibat trauma yang lebih parah.

Perlindungan negara bagi anak telah tertuang dalam bentuk peraturan perundang-undangan, diantaranya UUPA dan UU SPPA. Dalam peraturan perundang-undangan tersebut telah diatur hal-hal khusus dalam menyelesaikan kasus anak, baik anak sebagai pelaku maupun anak sebagai korban. Hal penting adalah dalam menghadapi anak diperlukan cara-cara khusus sebagaimana yang telah diatur dalam kedua peraturan perundang-undangan tersebut. Penggunaan UUPA dan Qanun Jinayat yang memberikan kewenangan mengadili kepada 2 (dua) lembaga peradilan dalam mengadili kasus yang sama, yaitu kasus kekerasan seksual pada anak, menimbulkan pro dan kontra baik dalam kalangan praktisi, akademisi, maupun dalam kalangan masyarakat. Pro dan kontra ini dikaitkan dengan hal-hal positif dan negatif dari kedua peraturan perundang-undangan tersebut dalam menyelesaikan kasus yang sama. Di sisi lain, dengan penerapan syariat Islam dan melalui penerapan Qanun Jinayat juga membuka ruang pengisian kekosongan hukum pada beberapa aspek, meskipun membutuhkan

Copyright $\odot$ 2019, LITIGASI, p-ISSN: 0853-7100; e-ISSN: 2442-2274 
harmonisasi pada proses penerapan hukum. Hal demikian diperlukan untuk memastikan terpenuhinya aspek keadilan bagi korban dan masyarakat serta kepastian dalam penegakan hukumnya di Aceh.

Umumnya, masyarakat bahkan pemerintah daerah sekalipun lebih reaktif dalam mencermati kasus kekerasan yang selama ini terjadi di Aceh. Kasus-kasus yang memunculkan perhatian publik kemudian mendorong adanya perhatian khusus dari elit politik. Sayangnya, perhatian itu sifatnya kontemporer yang hanya terjadi dalam jangka pendek semata. Dengan kata lain, saat ini penanganan masih fokus pada aspek hukum (setelah kasus terjadi) dan belum ada kepastian penegakan hukum karena semua aspek hukum memiliki keterkaitan dalam penyelesaian tetapi praktisnya berjalan sendiri-sendiri baik hukum adat, hukum Islam dan hukum nasional. Kekerasan yang terjadi pada anak dipengaruhi oleh latar belakang budaya patriarkhi, relasi kuasa yang timpang dan berbagai kesenjangan lainnya yang menyebabkan terjadinya kekerasan pada anak. Oleh karena itu, penanganan terhadap permasalahan kekerasan pada anak memerlukan mekanisme yang komprehensif sehingga dapat membantu para korban melewati proses sulit dan menjalani hidupnya dengan baik serta mencapai kebahagiaan dalam kehidupan.

Banyak kasus kekerasan yang dialami perempuan dan anak yang tidak muncul ke permukaan dengan berbagai faktor penyebabnya. Masih kentalnya budaya patriakhi dan minimnya pengetahuan serta pemahaman mengenai hakhak perempuan dan anak ikut andil dalam tumbuh suburnya kekerasan di Aceh. Kurangnya pengetahuan dan pemahaman yang dimiliki menyebabkan perempuan dan anak kerap mengalami tindakan kekerasan sehingga menjadi proses yang terus menerus berlangsung bahkan puluhan tahun lamanya. Berdasarkan wawancara yang dilakukan dengan Abdullah Abdul Muthaleb, Staf Ahli P2TP2A Rumoh Putroe Aceh, mengatakan bahwa ketika bicara soal kekerasan seksual terhadap anak dianggap adalah hal yang lebih "tabu" untuk diungkap terkait

Copyright $\odot$ 2019, LITIGASI, p-ISSN: 0853-7100; e-ISSN: 2442-2274 
dengan kekerasan seksual. Melaporkan kasus tersebut dianggap membuka aib sehingga harus ditutup rapat-rapat agar tidak diketahui publik. Bahkan bukan hanya keluarga, tetapi lingkungan masyarakat juga belum sepenuhnya memberikan ruang bagi perempuan untuk berbicara dan menentukan keputusannya sendiri dalam menghadapi kasus kekerasan yang menimpanya.

Apabila ditinjau dari teori keadilan, menurut John Rawls keadilan adalah kebijakan utama dari hadirnya institusi-institusi sosial, dimana kebaikan bagi seluruh masyarakat tidak dapat mengenyampingkan atau mengganggu rasa keadilan dari setiap orang yang memperoleh rasa keadilan. Menurutnya konstitusi dan hukum adalah basis pelaksanaan hak dan kewajiban individu dalam interaksi sosial. Dalam konstitusi diatur kesamaan minimum bagi segenap warga masyarakat. Lebih jauh, eksistensi suatu masyarakat tergantung pada pengaturan formal melalui hukum beserta lembaga-lembaga pendukungnya. Oleh karena itu, dalam kehidupan bermasyarakat perlu konsistensi para penegak hukum dalam pelaksanaan peraturan dan hukum itu sendiri. Berdasarkan uraian teori keadilan menurut John Rawls di atas, dapat dikaitkan dengan keberadaan dualisme hukum dalam penyelesaian kasus kekerasan seksual terhadap anak di Aceh. Dengan adanya dualisme hukum tersebut, akan menimbulkan inkonsistensi bagi aparat penegak hukum dalam pemeriksaan dan penyelesaian perkara. Aparat penegak hukum mengalami kebingungan akan menggunakan pengaturan formal yang mana dalam penyelesaian kasus kekerasan seksual terhadap anak.

Hal ini tentu saja akan memakan waktu yang lama, belum lagi ketika aparat penegak hukum telah menggunakan salah satu pengaturan formal, oleh kejaksaan berkasnya dikembalikan dan diharuskan untuk menggunakan pengaturan formal lainnya. Waktu yang lama ini tentu saja memberikan ketidakadilan bagi korban, dimana selama proses pemeriksaan pelaku dapat saja mengganggu atau mengancam korban, sehingga trauma korban akan semakin bertambah. Dilihat dari teori kewenangan, dimana kewenangan merupakan

Copyright $\odot$ 2019, LITIGASI, p-ISSN: 0853-7100; e-ISSN: 2442-2274 
kekuasaan formal yang berasal dari undang-undang. Kekuasaan di sini merupakan kekuasaan dalam menyelesaikan kasus kekerasan seksual pada anak yang diberikan kepada lembaga peradilan. Kewenangan lembaga peradilan dalam menyelesaikan kasus disebut dengan kewenangan mengadili (kompetensi). Kewenangan mengadili (kompetensi) adalah kewenangan untuk menyelesaikan suatu perkara oleh lembaga peradilan. Pengadilan dalam mengadili suatu perkara memiliki 2 (dua) kewenangan, yaitu kewenangan mutlak (absolute competentie) dan kewenangan relatif (relative competentie). Kewenangan mutlak adalah kewenangan badan peradilan dalam memeriksa jenis perkara tertentu yang secara mutlak tidak dapat diperiksa oleh badan pengadilan lain, baik dalam lingkungan pengadilan yang sama (pengadilan negeri dengan pengadilan tinggi) maupun dalam lingkungan peradilan yang lain (pengadilan negeri dengan pengadilan agama). Sedangkan kewenangan relatif adalah kekuasaan atau wewenang yang diberikan kepada pengadilan dalam lingkungan peradilan yang sama jenis dan tingkatan yang berhubungan dengan wilayah hukum pengadilan dan wilayah tempat tinggal/tempat kediaman atau domisili pihak yang berperkara.

Alasan penggunaan UUPA dalam menyelesaikan kasus kekerasan seksual terhadap anak menjadi pilihan utama karena:

a. UUPA menjadi sebuah kebijakan negara yang sudah berlaku cukup lama dan telah mengalami beberapa kali perubahan dengan tujuan menjadi kerangka hukum yang kuat, komprehensif dan bisa menjawab berbagai kekosongan hukum menyangkut dengan seluruh aspek perlindungan anak, khususnya anak-anak yang menjadi korban kekerasan dan penelantaran, juga hakikat kemanusiaan sesuai dengan nilai-nilai keadilan bagi korban.

b. UUPA telah melalui berbagai proses harmonisasi dan perubahan, yaitu Undang-Undang Nomor 23 Tahun 2002 tentang Perlindungan Anak juncto Undang-Undang Nomor 17 Tahun 2016 tentang Penetapan Perppu Nomor

Copyright $\odot$ 2019, LITIGASI, p-ISSN: 0853-7100; e-ISSN: 2442-2274 
1 Tahun 2016 tentang Perubahan Kedua Atas Undang-Undang Nomor 23 Tahun 2002 tentang Perlindungan Anak.

c. UUPA bersifat sangat khusus dan istimewa karena hanya mengatur satu kelompok umur yaitu usia 0 tahun sampai dengan 18 tahun.

d. Ancaman dalam UUPA lebih berat dan bersifat kumulatif. Berbeda dengan ancaman hukuman dalam Qanun Jinayat yang bersifat alternatif yang membuat hukumannya menjadi tidak setimpal dengan perbuatannya. Meskipun ancaman maksimal dari kedua peraturan perundang-undangan ini sama. Keistimewaan Qanun Jinayat terletak pada hukuman cambuknya, sehingga hukuman cambuk lebih sering digunakan daripada hukuman penjara. Meskipun para jaksa dapat menuntut dengan hukuman penjara, namun yang memutuskan adalah hakim. Dan dalam Qanun Jinayat hukumannya lebih ringan dan bersifat alternatif yaitu pidana penjara atau pidana cambuk atau denda, sehingga hakim dapat memutuskan dengan putusan yang berbeda dengan tuntutan jaksa.

e. UUPA merupakan peraturan perundang-undangan yang mengatur hal yang sangat spesifik terkait tindak pidana yang melibatkan anak. Sedangkan Qanun Jinayat bukan merupakan lex specialis dan tidak spesifik mengatur tentang anak.

f. Penerapan UUPA sudah diatur dengan jelas dalam UU tersebut meskipun masih terdapat banyak kendala dalam penafsiran dan penerapannya. Namun, pada Qanun Jinayat, penerapannya menimbulkan kendala bagi jaksa, terutama terkait eksekusinya. Seharusnya eksekusi hukuman dalam Qanun Jinayat dibiayai oleh pemerintah Aceh. Namun faktanya, pemerintah Aceh tidak menganggarkan dana untuk itu.

g. Mahkamah Syar'iyah tidak memiliki kewenangan menahan pelaku sebagaimana kewenangan yang ada pada pengadilan negeri. Penahanan Mahkamah Syar'iyah terhadap pelaku memiliki selisih waktu yang jauh dengan penyelesaian perkaranya, sehingga pelakunya dibebaskan. Meskipun

Copyright @ 9 2019, LITIGASI, p-ISSN: 0853-7100; e-ISSN: 2442-2274 
sebenarnya jaksa dapat meminta penahanan untuk kepentingan eksekusi paling lama 30 (tiga puluh) hari.

h. Hakim yang mengadili kasus anak pada pengadilan negeri memiliki sertifikat dengan keahlian khusus dalam mengadili anak. Sedangkan hakim Mahkamah Syar'iyah memiliki perspektif yang mengambang karena tidak memiliki keahlian khusus dalam menangani masalah anak.

Adanya dualisme hukum antara penggunaan UUPA dan Qanun Jinayat yang memberikan kewenangan mengadili kasus kekerasan seksual pada 2 (dua) lembaga peradilan yang berbeda, menimbulkan masalah dalam penegakannya. Selain itu, dualisme menyebabkan kewibawaan aparat penegak hukum menjadi turun karena kebingunan yang ditimbulkan oleh 2 (dua) peraturan perundangundangan ini. Karena pada dasarnya kedua peraturan perundang-undangan ini tidak harmonis dan tidak ada hubungan lex specialis dan lex generalis. Sehingga apabila ingin menerapkan Qanun Jinayat yang dianggap sebagai keistimewaan Daerah Aceh, maka perlu dilakukan perbaikan dan harmonisasi antara keduanya sehingga tidak menyebabkan kendala penerapannya menjadi penghambat bagi korban dalam mendapatkan keadilan. Oleh karena itu, kewenangan mengadili terhadap kasus kekerasan seksual pada anak akan lebih baik bila berada pada pengadilan negeri dengan pertimbangan-pertimbangan yang telah disebutkan di atas. Diharapkan agar dualisme hukum dalam penanganan kasus ini dapat segera terselesaikan.

Copyright $\odot$ 2019, LITIGASI, p-ISSN: 0853-7100; e-ISSN: 2442-2274 


\section{SIMPULAN DAN SARAN}

\section{A. Simpulan}

Implementasi Kewenangan absolut pada lembaga peradilan terkait penyelesaian perkara kekerasan seksual terhadap anak di Aceh, pengadilan negeri yang kewenangannya diberikan oleh UUPA lebih berwenang dibandingkan dengan Mahkamah Syar'iyah yang kewenangannya diberikan oleh Qanun Jinayat, karena: ancaman dalam UUPA lebih berat dan bersifat kumulatif, sedangkan Qanun Jinayat lebih ringan dan bersifat alternatif, UUPA mengatur hal spesifik tentang kasus anak, sedangkan Jinayat tidak sepesifik, penerapan UUPA beserta perubahannya masih terkendala, ditambah lagi dengan adanya Qanun jinayat, ditemukan sejumlah permasalahan terkait dengan ketidaktersediaan fasilitas ruang tahanan dan anggaran selama proses pemeriksaan perkara dan belum adanya kerjasama dengan pihak lembaga pemasyarakatan (lapas) bagi terhukum jinayat, hakim pengadilan negeri pada umumnya telah memiliki sertifikat khusus anak, sedangkan hakim Mahkamah Syar'iyah pada saat penelitian ini dilakukan belum memiliki sertifikat khusus anak.

\section{B. Saran}

Diharapkan kepada Pemerintah Aceh agar dapat dilakukan kajian ulang terhadap Qanun Jinayat terutama terkait pasal tentang anak. Apabila Qanun Jinayat ingin benar-benar diterapkan, maka diharapkan adanya komitmen yang kuat dari semua pihak. Penyelesaian kasus kekerasan seksual terhadap anak, sebaiknya dikembalikan kepada UUPA, aparat penegak hukum harus dapat menjalin koordinasi, sinkronisasi dan komunikasi antara hakim dengan jaksa, dan jaksa dengan penyidik. Karena dibutuhkan satu kesepakatan dalam penyelesaian kasus kekerasan seksual terhadap anak sehingga efektifitas waktu dapat terjaga.

Copyright $\odot$ 2019, LITIGASI, p-ISSN: 0853-7100; e-ISSN: 2442-2274 
Available online at: http://ejournal.unpas.ac.id/index.php/litigasi

Litigasi, Vol. 20 (2) Oktober, 2019, p.267-290

DOI: http://dx.doi.org/10.23969/litigasi.v20i2.1561

\section{DAFTAR PUSTAKA}

Luhulima, A. S. (2000). Pemahaman Tentang Bentuk-bentuk Kekerasan Terhadap Perempuan Alternatif Pemecahannya. Jakarta: Alumni.

Rasyid, R. (2007). Hukum Acara Peradilan Agama. Jakarta: Raja Grafindo Persada.

Soeroso, R. (2001). Praktek Hukum Acara Perdata: Tata Cara dan Proses Persidangan. Jakarta: Sinar Grafika.

Susilawati, S. (2001). Penyebab Terjadinya Kekerasan Seksual Terhadap Perempuan. Bandar Lampung: Universitas Lampung.

Copyright @ 2019, LITIGASI, p-ISSN: 0853-7100; e-ISSN: 2442-2274 